\title{
Global tobacco advertising, promotion and sponsorship regulation: what's old, what's new and where to next?
}

\author{
Becky Freeman $\odot,{ }^{1}$ Christina Watts $\odot,{ }^{2}$ Putu Ayu Swandewi Astuti $\odot^{3}$
}

\begin{abstract}
'School of Public Health, The University of Sydney Faculty of Medicine and Health, Sydney, New South Wales, Australia ${ }^{2}$ Daffodil Centre, Faulty of Medicine and Health, The Univeristy of Sydney, Sydney, New South Wales, Australia ${ }^{3}$ Department of Public Health and Preventive Medicine, Udayana University Faculty of Medicine, Denpasar, Bali, Indonesia
\end{abstract}

\section{Correspondence to}

Dr Becky Freeman, School of Public Health, The University of Sydney Faculty of Medicine and Health, Sydney, NSW 2006, Australia;

becky.freeman@sydney.edu.au

Received 11 June 2021

Accepted 23 September 2021

Check for updates

(c) Author(s) (or their employer(s)) 2022. No commercial re-use. See rights and permissions. Published by BMJ.

To cite: Freeman B, Watts $C$, Astuti PAS. Tob Control 2022;31:216-221.

\section{ABSTRACT}

Tobacco advertising, promotion and sponsorship (TAPS) bans are a cornerstone of comprehensive tobacco control laws. Global progress in implementing TAPS bans has been enabled by the adoption of the WHO Framework Convention on Tobacco Control. Innovative TAPS policies are in place internationally and include: point-of-sale display bans, plain packaging of products, industry spending on TAPS disclosure reporting, bans on retailer incentive programmes, and regulation of TAPS in entertainment and online media. However, there is an over-reliance on entertainment and digital content producers and platforms to self-regulate TAPS. Ensuring TAPS laws are regularly examined to limit loopholes and remove exemptions is crucial to continued success. The definition of what constitutes TAPS can allow the tobacco industry to deploy corporate communication and political campaigns that skirt TAPS bans. TAPS laws must also maintain pace with the changing media landscape, which includes monitoring and reporting TAPS that cross international borders, primarily through digital media platforms. Limiting tobacco retail supply will also serve to prevent the continued undermining of TAPS bans. Leveraging global corporation to ensure enforcement of TAPS bans across borders is urgently needed.

\section{INTRODUCTION}

Direct tobacco advertising has long been banned on broadcast television and radio in most parts of the world. Thirty years ago, however, when this journal was first launched, it was not uncommon for tobacco advertising, promotion and sponsorship (TAPS) laws to include exemptions for tobacco sponsorship of major sporting events, including those with a global television audience, like Formula One auto-racing. ${ }^{1}$ Today, Philip Morris International (PMI) and British American Tobacco continue to back Formula One teams under the guise of corporate communication campaigns that are claimed to 'encourage dialogue around positive change; our own and that of others'. ${ }^{2}$ The green livery of the PMI Mission Winnow campaign (figure 1, image source: https:// www.formula1.com/en/latest/article.first-lookferrari-unveil-hotly-anticipated-sf21-with-splashof-green-on.5ubReuuvkubyzgSfmUmex1.html) will prominently feature on the Ferrari team cars during the 2021 racing season in countries that have not closed loopholes that allow tobacco company branding that is not directly linked to a tobacco product or brand. ${ }^{3}$ But, as all races will continue to be broadcast on television and online internationally, this form of TAPS will easily cross borders

\section{What this paper adds}

- Tobacco advertising bans are unevenly applied to online and entertainment media.

- In order to maximise the impact of tobacco advertising bans, policies must also address evolving forms of promotion, including corporate communication campaigns and retail availability.

and readily weaken even the strongest of domestic laws. Tobacco industry sponsorship of motorsport has been ongoing for decades and is a well-worn technique that has adjusted to changing advertising laws and media platforms. ${ }^{4}$ Seemingly, everything old is new again when it comes to tobacco industry advertising tactics, be that the use of celebritiesnow known as digital influencers-to aspirational and pro-tobacco imagery on digital media instead of in fashion magazines and print media.

\section{Evolution of TAPS and TAPS laws}

TAPS laws must continue to progress and address the seemingly endless ways the tobacco industry attempts to promote its products, maintain current customers, lure back those who quit smoking and entice new users. When only some forms of TAPS are regulated, the industry redirects its promotional efforts, and budget, to exempt promotions. ${ }^{5}$ A TAPS ban that is heralded as comprehensive and progressive can quickly be outdated, or no longer fit for purpose, if it is not updated to meet innovations in promotional opportunities. The rapid change to a predominantly digital media environment, including the explosive rise of online social media, has also enabled the tobacco industry to exploit new forms of promotion. ${ }^{6}$ This combination of significant TAPS exemptions coupled with new forms of media is not an intractable obstacle and there are many examples of jurisdictions that have adopted novel policy approaches to further limit TAPS activities and exposure. A number of these key policies are outlined below and a brief discussion of the next steps in TAPS regulation concludes the paper. Policy issues surrounding noncombustible tobacco and nicotine devices are not included in this paper, but are explored in depth in another anniversary issue paper by Ling et al. ${ }^{7}$ Of importance to note here is that the exclusion of non-combustible tobacco and nicotine devices from TAPS laws means that the promotion of these products can also serve to promote tobacco brands 


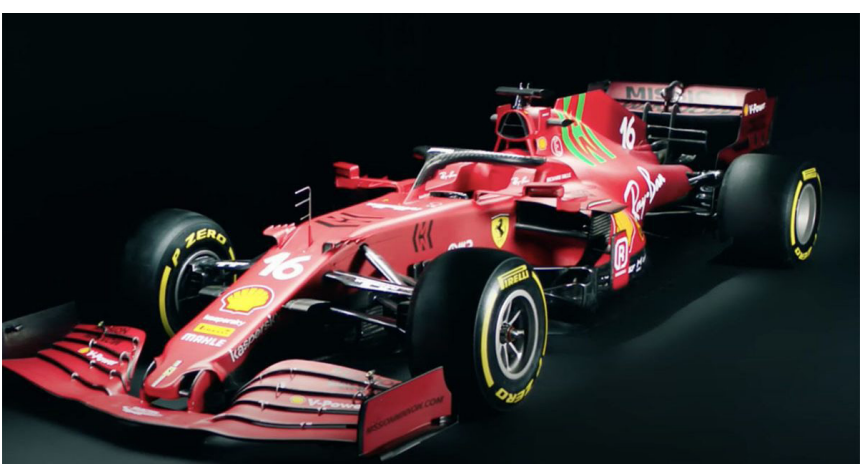

Figure 1 Scuderia Ferrari Formula One car for the 2021 season, featuring the Mission Winnow green livery.

and tobacco companies. At the sixth session of the Conference of the Parties to the WHO Framework Convention on Tobacco Control (FCTC) in October 2014, Parties were urged to consider banning or restricting advertising, promotion and sponsorship of electronic nicotine delivery systems. ${ }^{8}$

\section{Global status of tobacco advertising laws}

Article 13 of the WHO (FCTC) recognises the crucial role TAPS bans play in effective tobacco control and does include banning cross-border TAPS as part of a comprehensive approach. ${ }^{9}$ Parties to the WHO FCTC recognise the ongoing difficulty in monitoring and enforcing cross-border TAPS bans and have initiated a process to update the Article 13 guidelines to reflect the dramatically changed media landscape since the guidelines were first adopted in $2008 .^{10}$ Parties have also called for a mechanism to enable more effective global cooperation in managing crossborder TAPS. ${ }^{11}$ The European Union, for example, requires all member states to ban cross-border tobacco advertising and sponsorship and actively monitors and enforces these provisions. ${ }^{12}$

Based on 2018 Party reports to the WHO FCTC, 18\% of the world population is covered by the 'highest level' of TAPS bans. ${ }^{13}$ These highest level bans include both (1) direct advertising bans: national television and radio, local magazines and newspapers, billboards and outdoor advertising, and point-ofsale (POS) advertising material (indoor) and (2) indirect advertising bans: free distribution of tobacco products in the mail or through other means, promotional discounts, non-tobacco goods and services identified with tobacco brand names (brand stretching), brand names of non-tobacco products used for tobacco products (brand sharing), appearance of tobacco brands (product placement) or tobacco products in television and/or films, and sponsorship (contributions and/or publicity of contributions). While this list of types of TAPS is broad ranging, it does not fully capture commonplace promotions like the retail display of tobacco products, on-pack branding, online promotions, and retailer incentive and reward programmes. A glossary of key advertising terms relevant to tobacco control is available online. ${ }^{14}$ Many Parties have also enacted laws that do extend to cover these additional promotional activities and all received Article 13-relevant regulatory reports can be searched through the online database. ${ }^{15}$

For the purposes of this paper, the WHO FCTC definitions of TAPS are used: tobacco advertising and promotion is defined as 'any form of commercial communication, recommendation or action with the aim, effect or likely effect of promoting a tobacco product or tobacco use either directly or indirectly' and tobacco sponsorship as 'any form of contribution to any event, activity or individual with the aim, effect or likely effect of promoting a tobacco product or tobacco use either directly or indirectly'. ${ }^{16}$

\section{Evolution of TAPS and TAPS laws}

TAPS laws must continue to progress and address the seemingly endless ways the tobacco industry attempts to promote its products, maintain current customers, lure back those who quit smoking and entice new users. When only some forms of TAPS are regulated, the industry redirects its promotional efforts, and budget, to exempt promotions. ${ }^{5}$ A TAPS ban that is heralded as comprehensive and progressive can quickly be outdated, or no longer fit for purpose, if it is not updated to meet innovations in promotional opportunities. The rapid change to a predominantly digital media environment, including the explosive rise of online social media, has also enabled the tobacco industry to exploit new forms of promotion. ${ }^{6}$ This combination of significant TAPS exemptions coupled with new forms of media is not an intractable obstacle and there are many examples of jurisdictions that have adopted novel policy approaches to further limit TAPS activities and exposure. A number of these key policies are outlined below and a brief discussion of the next steps in TAPS regulation concludes the paper. Policy issues surrounding non-combustible tobacco and nicotine devices are not included in this paper, but are explored in depth in another anniversary issue paper by Ling et al.

\section{POS marketing and retail displays}

Tobacco retailers are not neutral tobacco purchasing outlets, they are a key pillar in the promotion of tobacco products. When POS tobacco marketing bans were first introduced, they only captured things like in-store promotional posters, banners, bunting and stickers that featured tobacco brands. Consequently, the display of tobacco products at POS exploded in size and scope, with the packages themselves arranged to create eyecatching in-store billboards, dubbed 'power walls'. ${ }^{17}$ In 2005, the Canadian province of Saskatchewan was the first jurisdiction in the world to ban the POS display of tobacco products, requiring them to be hidden from view at POS. This followed on from a tobacco industry legal challenge that first saw the provincial law struck down in 2002. According to the Campaign for Tobacco Free Kids online database of tobacco control laws from 210 countries, 39 countries completely ban the display of tobacco products at POS and another 42 countries only allow for some POS display exemptions such as at duty-free outlets and tobacconists. ${ }^{18}$ Implementing POS tobacco display bans results in lower exposure to tobacco marketing and less frequent impulse purchasing of cigarettes. ${ }^{19}$ In Indonesia, a country with only minimal TAPS laws, and no POS marketing or display ban, the surge in small convenience store operators near homes ${ }^{20}$ means an even greater concentration of tobacco retailers and exposure to in-store power walls.

\section{Retailer incentive programmes}

In the USA, the largest tobacco manufacturers are required to report on their domestic advertising and promotional activity to the Federal Trade Commission (FTC). These data are then periodically released by the FTC in an aggregated report. While TAPS laws are relatively weak in the USA compared with other high-income countries, ${ }^{21}$ the report reveals an overwhelming concentration of spending on retail incentive programmes. The total amount spent on US domestic cigarette advertising and promotion was US\$7.62 billion in $2019 .{ }^{22}$ The largest single category of these TAPS expenditures was price discounts paid 
to cigarette retailers in order to reduce the price of cigarettes to consumers, which accounted for US $\$ 5.696$ billion. A further US\$917.4 million was spent on price discounts to wholesalers. These price discounts can reduce the impact of tobacco tax increases and further enable youth and young adults, who are more price sensitive, to purchase and use tobacco. ${ }^{23}$ Spending on promotional allowances paid to cigarette retailers (payments for stocking, shelving, displaying, and merchandising brands, volume rebates, and incentive payments) was US $\$ 174.9$ million and spending on promotional allowances paid to cigarette wholesalers (payments for volume rebates, incentive payments, value-added services and promotional executions) totalled $\$ 336.6$ million. When price discounts and promotional allowances paid to cigarette retailers and wholesalers are combined, they total $\$ 7.125$ billion, and account for $93.4 \%$ of all 2019 reported TAPS expenditures in the USA alone.

These data reveal the incredible importance of retailer incentive programmes-even in markets where tobacco can be legally promoted by other means. ${ }^{24}$ Former tobacco company employees have corroborated that this type of marketing activity is of high importance in driving sales. ${ }^{25} \mathrm{~A}$ first step in better regulating retailer incentive programmes would be to require TAPS spending disclosure and reporting in many more nations. Country comparisons could then be drawn and a far more accurate picture of how these transnational companies are promoting products globally, and how much they are spending, could be determined. Effective regulation could then be more achievable when armed with quality data. Sharing data and working collaboratively are baked into the WHO FCTC and this is just one practical way this could lead to reducing TAPS exposure and strengthening regulation.

This concentration of retailer incentive programme spending, primarily designed to manipulate the price of tobacco products and entice retailers to increase sales, needs to be better captured under TAPS bans. In 2016, the Canadian province of Quebec banned the offering to retailers of 'rebates, gratuities or any other form of benefit related to the sale or the retail price of a tobacco product'. ${ }^{26}$ Scottish $^{27}$ and Australian ${ }^{25}$ research reveals that retailers are also granted vouchers, prizes, trips, tickets to events, and invited to exclusive parties as part of retailer reward and education programmes. Globally, there is a scarcity of research and evaluation of tobacco retailer incentive programmes. There is little evidence of monitoring or compliance in countries that assume these sorts of incentives are already captured under existing comprehensive TAPS bans, despite the lack of explicit language banning these practices. ${ }^{25}$ Retailer price discounts can then be directly promoted to consumers at POS in countries that do not ban price promotions. These price promotions are further exacerbated by a lack of minimal floor pricing for tobacco products-a policy that has only nominal adoption globally. ${ }^{28}$ In a four-country comparative study, smokers in the two countries that ban price promotions (Canada and the UK) do still report being exposed to this marketing practice, revealing that legislative extent and compliance with tobacco control measures can undercut TAPS measures. ${ }^{29}$

\section{Plain packaging of tobacco products}

Bright colours, satin finishes, embossed lettering, modern graphics, metallic foils, inserts and slide openings ${ }^{30}$ are just some of the packaging flourishes the industry has used to make their products more attractive and seem less harmful. Pictorial health warnings on tobacco products are commonplace, with 118 countries/jurisdictions requiring graphic images on packages, which encompasses $58 \%$ of the world's population, but these warnings are often undermined by innovative packaging design elements. ${ }^{3132}$ In 2012, Australia became the first country in the world to mandate the removal of all branding elements, save the name of the product, from tobacco packaging. Tobacco packages in Australia are standardised and dominated by large pictorial health warnings and quit information, with only the name of the tobacco brand appearing in small font against a green-brown background. As of March 2021, 18 countries including Israel, Saudi Arabia, Uruguay and Thailand have adopted, and put into force, tobacco plain packaging laws. ${ }^{33}$ Canadian plain packaging laws, implemented in 2020, extend to the design and shape of the cigarette itself, restricting the length and width of cigarettes, meaning that slim and superslim cigarettes, that are associated with glamour and femininity, are now banned from sale. ${ }^{34}$

Plain packaging reduces positive perceptions of smoking and dissuades tobacco use, particularly when part of a comprehensive ban on TAPS. ${ }^{35}$ Plain packaging also appears to be successful in reducing the appeal of smoking and tobacco packaging in low-income settings, but in order to rapidly diffuse plain packaging policy to more low/middle-income countries, ${ }^{36}$ there is an urgent need to conduct focused research outside of high-income countries. $^{37}$

\section{TAPS in entertainment and online media}

The WHO FCTC Article 13 guidelines state that the depiction of tobacco in entertainment media, such as in movies, online videos and computer games, is a form of TAPS. ${ }^{9}$ It is the commercial nature of these forms of entertainment media that define the tobacco depictions they contain as TAPS, regardless of any tobacco industry involvement in the creation or funding of the content. Much of this entertainment media content is accessed through social media and streaming platforms on personal internet-enabled devices, such as smartphones. And, just like for international sports events as mentioned above, this type of content can also be created, uploaded or broadcast in one country and then viewed and shared in another. Cross-border digital media consumption provides more channels through which the tobacco industry can circumvent TAPS bans. Time spent online and consumption of online entertainment media at home have been even more pronounced during COVID-19 stay home orders, ${ }^{38}$ and emboldened the Indonesian tobacco company Djarum, through its foundation, to sponsor online, at home, dance and food events. ${ }^{39}$

While the tobacco industry is unable to sponsor tobacco depictions in movies and films in countries with comprehensive TAPS bans, these policies rarely extend to unsponsored tobacco depictions in entertainment media. Since 2012, India has required movies depicting smoking to be accompanied by a 100-second government-issued anti-smoking ad and a static health warning at the bottom of the screen must be visible for the duration of the tobacco depiction. ${ }^{40}$ Any accompanying tobacco product brand names that appear on screen must be blurred out. Other countries, including China and Thailand, regulate the smoking content permissible in television and films. Although the association between smoking depictions in movies and the increased risk of youth smoking uptake has been replicated in several studies ${ }^{41}$ there is no research or evaluation on the impact of policy interventions to reduce tobacco depiction exposure. ${ }^{40}$

In addition to government policy action, global media content producers and streaming services, such as Disney ${ }^{42}$ and Netflix, ${ }^{43}$ have made public commitments to curb the amount of tobacco depictions included in new content, particularly that aimed at 
younger audiences. Such a move only came after it was revealed that tobacco depictions on Netflix shows popular with young people had increased over time. ${ }^{44}$ An online database of smoking depictions in media maintained by the University of California San Francisco documents the continued promotion of tobacco use in both Disney and Netflix content-among all other major media companies. $^{45}$

About half (91 of $180,50.6 \%)$ of countries reporting to the WHO FCTC on TAPS regulations say that their TAPS ban includes the domestic internet. ${ }^{46}$ Direct, paid tobacco ads on online media are the easiest form of online TAPS to recognise, monitor and enforce. Popular online platforms also have their own policies that ban this type of promotion (more on these policies follows below). Countries can more easily ban online TAPS that originate in their own countries, but without international cooperation, it is more difficult to ban those that originate from another country and then 'leak' across digital borders. It can also be very difficult to distinguish between what is a direct, paid tobacco promotion versus content that does not have a commercial connection. For example, a 2018 investigation found that tobacco companies were engaging popular social media influencers to promote tobacco products through their highly viewed social media profiles. ${ }^{47}$ The influencers' posts did not disclose that they were tobacco advisements or that they had received tobacco incentives to post tobacco depictions and branding on their profile feeds and pages. Influencers are also heavily involved in the promotion of electronic cigarettes and other non-combustible tobacco and nicotine devices. ${ }^{48}$

Popular social media platforms, including Facebook, ${ }^{49}$ Instagram $^{50}$ and Twitter, ${ }^{51}$ have adopted policies that claim to ban tobacco advertising. However, these policies do not apply to political and corporate messaging ads sponsored by the tobacco industry, they do not restrict tobacco companies from using hashtags to attract social media post attention, ${ }^{52}$ nor do they in any way restrict tobacco companies from operating accounts on these platforms. PMI, for example, operates a Facebook page that has more than 1 million followers. ${ }^{53}$ Google also has an advertising policy on dangerous products or services and prohibits tobacco or any products containing tobacco; products that form a component of a tobacco product, as well as products and services that directly facilitate or promote tobacco consumption; and products designed to simulate tobacco smoking. ${ }^{54}$ Google searches for tobacco retailers though, for example, provide localised results and direct links to sales outlets. There is also no evidence that these voluntary policies lead to reduced TAPS exposure. This rapidly evolving media environment, coupled with lax regulation of social media communication platforms, including the over-reliance on platform self-regulation, ${ }^{55}$ means that extending comprehensive TAPS bans to truly include entertainment and online media is incredibly challenging. Mandating that all social media platforms ban tobacco advertising, including by influencers is crucial, but this also must include requirements that these platforms report on how they are ensuring the law is being implemented and enforced across their sites. Currently, it is largely tobacco control stakeholders that are monitoring the amount and type of TAPS on social media platforms ${ }^{56}$ and more of this burden needs to be shifted on to the companies themselves.

Other key challenges presented to effectively regulating TAPS in entertainment and online media include: social media enables users to be content creators and sharers, blurring the lines between consumers and brand owners; systematically monitoring both tobacco industry promotional activities and tobacco depictions; countries that have not ratified the WHO FCTC may also be a source of cross-border TAPS; and lack of enforcement of internet-based TAPS bans. ${ }^{57}$

\section{Next steps in TAPS regulation}

Despite global progress in adopting TAPS bans and regulations, no country has managed to completely silence tobacco industry promotions. In addition to following the lead of countries that have adopted the measures described above and followed best practice approaches, there are two other key TAPS issues that warrant additional action: corporate communications and retail availability.

\section{Corporate communications}

In addition to TAPS and tobacco depictions in entertainment and online media, tobacco industry corporate communications campaigns have been well documented as a source of pro-tobacco messaging. These promotions, such a corporate social responsibility messaging, ${ }^{58}$ industry-funded foundation campaigns, ${ }^{59}$ industry funding of science and research, political/lobbying efforts, including paid editorial (advertorial) in news media, ${ }^{60}$ and unpaid posts on social media from both company-branded accounts and employees ${ }^{61}$ sidestep TAPS laws and skirt TAPS definitions. Falling under 'legitimate expression' exemptions, ${ }^{16}$ these corporate communications nonetheless use the same media platforms and serve the same purpose as direct advertising.

\section{Retail availability}

While there is significant room for nations to adopt innovations and advances in TAPS regulations in order to continue to build on the incremental success of previous work, the continued widespread retail availability of tobacco weakens actions to reduce TAPS connected with retail. The current WHO FCTC guidelines single out tobacco vending machines as primarily serving only to promote tobacco products and recommend that they be banned. ${ }^{9}$ At least 83 countries have national bans on tobacco vending machines. ${ }^{62}$ Tobacco sales are also commonly prohibited from pharmacies by both regulation and voluntary policies. Banning all online tobacco sales is another potential first step in limiting supply, particularly in light of evidence that the tobacco industry has developed mobile applications to enable online sales that can then also be used for tailored and direct marketing. ${ }^{63}$ Like other tobacco control policies, such as smoke-free laws, that have been incrementally extended and tightened, limiting where tobacco is sold seems increasingly possible. ${ }^{64}$

\section{CONCLUSION}

One of the limitations in assessing the global state of TAPS bans is the limited body of work reporting on the implementation and enforcement of TAPS laws and regulations. ${ }^{65}$ Published research tends to focus on why TAPS laws are needed, ${ }^{66}$ the impact of exposure to TAPS, ${ }^{67}$ how TAPS laws effect exposure to TAPS ${ }^{68}$ and potential impact on smoking attitudes, beliefs, and behaviours, ${ }^{70}$ and how the tobacco industry behaves in the face of newly adopted TAPS laws ${ }^{71}$ and subverts existing TAPS laws. ${ }^{72}$ While countries that are Party to the WHO FCTC Convention Secretariat self-report on the scope of TAPS laws, this reporting does not include details of enforcement activity, and existing exemptions and limitations of policy reach are not well described.

Countries that are committed to ending the promotion of tobacco products must not only strengthen their own domestic TAPS bans, but work with and support other nations to reduce cross-border TAPS. This will require more effective global 
cooperation in managing cross-border TAPS and a commitment from all nations to regularly update TAPS regulations in response to both new media and communications platforms and consumption patterns, and the evolving industry tactics that merge political interference, advertising and product development. Improving and updating TAPS laws must be a continual process in order to meet the highest global standards, coupled with leadership to develop new regulatory innovations, such as a complete end to the retail sale of tobacco products. ${ }^{73}$

Twitter Becky Freeman @DrBFreeman, Christina Watts @WattsChrissy90 and Putu Ayu Swandewi Astuti @drayuswandewi

Contributors BF conceived of the paper and prepared the first draft. CW and PASA contributed to writing and finalising the manuscript.

Funding The authors have not declared a specific grant for this research from any funding agency in the public, commercial or not-for-profit sectors.

Competing interests BF serves a paid expert advisor to the WHO FCTC Convention Secretariat on cross-border tobacco advertising.

Patient consent for publication Not required.

Provenance and peer review Commissioned; externally peer reviewed.

ORCID iDs

Becky Freeman http://orcid.org/0000-0002-2082-9612

Christina Watts http://orcid.org/0000-0002-3803-6151

Putu Ayu Swandewi Astuti http://orcid.org/0000-0002-4723-212X

\section{REFERENCES}

1 Chapman S. Anatomy of a campaign: the attempt to defeat the new South Wales (Australia) tobacco advertising Prohibition bill 1991. Tob Control 1992;1:50-6.

2 planetf1. Ferrari could bring mission Winnow branding back: planetf1, 2021. Available: https://www.planetf1.com/news/ferrari-mission-winnow-return/ [Accessed 1 June 2021].

3 Vital Strategies. Driving addiction F1 and tobacco advertising, 2020. Available: https:// exposetobacco.org/wp-content/uploads/Tobacco-Sponsorship-in-Formula-One.pdf [Accessed 31 Aug 2021].

4 Tactics T. Motorsport sponsorship, 2021. Available: https://tobaccotactics.org/wiki/ motorsport-sponsorship/ [Accessed 31 Aug 2021].

5 Blecher $\mathrm{E}$. The impact of tobacco advertising bans on consumption in developing countries. J Health Econ 2008;27:930-42.

6 Freeman B. New media and tobacco control. Tob Control 2012;21:139-44.

7 Ling P, Kim M, Egbe CO. Moving targets: how the rapidly changing tobacco and nicotine landscape creates advertising and promotion policy challenges. Tob Control 2022;31:221-7.

8 Conference of the Parties to the WHO Framework Convention on Tobacco Control. DECISION FCTC/COP6(9) Electronic nicotine delivery systems and electronic nonnicotine delivery systems, 2014. Available: https://apps.who.int/gb/fctc/PDF/cop6/ FCTC_COP6(9)-en.pdf?ua=1 [Accessed 31 Aug 2021].

9 WHO Framework Convention on Tobacco Control Secretariat. Guidelines for implementation of article 13 of the who framework convention on tobacco control, (tobacco advertising, promotion and sponsorship), 2008. Available: https://www.who. int/fctc/guidelines/article_13.pdf?ua=1 [Accessed 1 June 2021].

10 Conference of the Parties to the WHO Framework Convention on Tobacco Control. DECISION FCTC/COP8(17)Tobacco advertising, promotion and sponsorship: depiction of tobacco in entertainment media, 2018. Available: https://fctc.who.int/docs/ librariesprovider12/meeting-reports/fctc_cop8(17).pdf?sfvrsn=cd4f3d49_16\& download=true [Accessed 1 June 2021].

11 Conference of the Parties to the WHO Framework Convention on Tobacco Control. DECISION FCTC/COP7(5)Tobacco advertising, promotion and sponsorship: depiction of tobacco in entertainment media, 2016. Available: https://fctc. who.int/docs/ librariesprovider 12/meeting-reports/fctc_cop7_5_en.pdf?sfvrsn=f2653e3c_16\& download=true [Accessed 1 June 2021].

12 European Commission. Ban on cross-border tobacco advertising and sponsorship, 2021. Available: https://ec.europa.eu/health/tobacco/advertising_en [Accessed 1 June 2021].

13 World Health Organisation. WHO report on the global tobacco epidemic 2019: offer help to quit tobacco use, 2019. Available: https://www.who.int/teams/healthpromotion/tobacco-control/who-report-on-the-global-tobacco-epidemic-2019\& publication=9789241516204 [Accessed 1 June 2021].

14 Freeman B, Haslam I, Scollo M, et al. Glossary of key advertising terms. Chapter 11 Tobaco advertising and promotion. tobacco in Australia, 2012. Available: https:// www.tobaccoinaustralia.org.au/chapter-11-advertising/11-0-background [Accessed 1 Jun 2021].
15 WHO Framework Convention on Tobacco Control Secretariat. Article reports. demand reduction measures. article 13 tobacco advertising, promotion, and sponsorship, 2021. Available: https://untobaccocontrol.org/impldb/Article-13/

16 World Health Organisation. Who framework convention on tobacco control. Introduction. article 1 use of terms, 2003. Available: https://apps.who.int/iris/rest/ bitstreams/50793/retrieve [Accessed 1 Jun 2021].

17 Dewhirst T. POP goes the power wall? taking AIM at tobacco promotional strategies utilised at retail. . BMJ Publishing Group Ltd, 2004: 13. 209-10.

18 Campaign for Tobacco-Free Kids. Tobacco cortrol laws. Policy Area: Advertising Promotion \& Sponsorship, forms: Point of sale product display law status of: Banned, 2021. Available: https://www.tobaccocontrollaws.org/legislation/finder/\#_adban-tab [Accessed 1 Jun 2021].

19 Li L, Borland R, Fong GT, et al. Impact of point-of-sale tobacco display bans: findings from the International tobacco control four country survey. Health Educ Res 2013;28:898-910.

20 Desk N. Indonesia minimarket growth to outpace large retailers: Fitch ratings. The Jakarat Post, 2019. Available: https://www.thejakartapost.com/news/2019/01/23/ indonesia-minimarket-growth-to-outpace-large-retailers-fitch-ratings.html [Accessed 11 Jun 2021].

21 Fielding-Singh P, Epperson AE, Prochaska JJ. Tobacco product promotions remain ubiquitous and are associated with use and susceptibility to use among adolescents. Nicotine Tob Res 2021:23:397-401.

22 Federal Trade Commission. Cigarette report for 2019, 2021. Available: https://www. $\mathrm{ftc.gov/system/files/documents/reports/federal-trade-commission-cigarette-report-}$ 2019-smokeless-tobacco-report-2019/cigarette_report_for_2019.pdf [Accessed 1 Jun 2021].

23 Levy DT, Chaloupka F, Lindblom EN, et al. The US cigarette industry: an economic and marketing perspective. Tob Regul Sci 2019;5:156-68.

24 SEATCA. Indonesia: tobacco industry merges retailer incentives with brand promotions, 2017. Available: https://tobaccowatch.seatca.org/index.php/2017/07/ 28/indonesia-tobacco-industry-merges-retailer-incentives-with-brand-promotions/ [Accessed 11 Jun 2021].

25 Watts C, Burton S, Freeman B. 'The last line of marketing': covert tobacco marketing tactics as revealed by former tobacco industry employees. Glob Public Health 2021;16:1000-13.

26 Callard CD, Collishaw N. Cigarette pricing 1 year after new restrictions on tobacco industry retailer programmes in Quebec, Canada. Tob Control 2019;28:562-5.

27 Stead M, Eadie D, Purves Rl, et al. Tobacco companies' use of retailer incentives after a ban on point-of-sale tobacco displays in Scotland. Tob Control 2018:27:414-9.

28 Kong AY, King BA. Boosting the tobacco control vaccine: recognizing the role of the retail environment in addressing tobacco use and disparities. Tob Control 2021;30:e162-8.

29 El-Toukhy S, Choi K, Hitchman SC, et al. Banning tobacco price promotions, smokingrelated beliefs and behaviour: findings from the International tobacco control four country (ITC 4C) survey. Tob Control 2018;27:310-8.

30 Moodie C, Hastings G. Tobacco packaging as promotion. . BMJ Publishing Group Ltd, 2010: 19. 168-70.

31 Canadian Cancer Society. Cigarette package health warnings: international status report, 6th edn, 2018. Available: https://www.tobaccofreekids.org/assets/global/pdfs/ en/WL_status_report_en.pdf [Accessed 23 Dec 2020].

32 Aleyan S, Driezen P, McNeill A, et al. Evaluating the impact of introducing standardized packaging with larger health-warning labels in England: findings from adult smokers within the EUREST-PLUS ITC Europe surveys. Eur J Public Health 2020;30:iii91-7.

33 Scollo M, Greenhalgh E. Tobacco in Australia: facts and issues. International flow-on effects, 2021. Available: https://www.tobaccoinaustralia.org.au/chapter-11advertising/indepth-11a-packaging-as-promotion/11a-6-international-flow-on-effects [Accessed 1 Jun 2021].

34 Canadian Cancer Society. Canada now has the best tobacco plain packaging regulations in the world, 2019. Available: https://www.newswire.ca/news-releases/ canada-now-has-the-best-tobacco-plain-packaging-regulations-in-the-world821342826.html [Accessed 1 Jun 2021]

35 Smith CN, Kraemer JD, Johnson AC, et al. Plain packaging of cigarettes: do we have sufficient evidence? Risk Manag Healthc Policy 2015;8:21.

36 Cohen JE, Zhou S, Goodchild M, et al. Plain packaging of tobacco products: lessons for the next round of implementing countries. Tob Induc Dis 2020;18:1-3.

37 Hughes N, Arora M, Grills N. Perceptions and impact of plain packaging of tobacco products in low and middle income countries, middle to upper income countries and low-income settings in high-income countries: a systematic review of the literature. BMJ Open 2016:6:e010391.

38 Flanagan EW, Beyl RA, Fearnbach SN, et al. The impact of COVID-19 Stay-At-Home orders on health behaviors in adults. Obesity 2021;29:438-45.

39 Djarum Foundation. INDONESIA Are Active With \#DancingAtHome and Enjoying Culinary Servings From the Garden to the Kitchen, 2020. Available: https://www. djarumfoundation.org/aktivitas/detail_kegiatan/1323/5/menaridirumahaja-dankuliner-indonesia-kaya-sajian-akhir-tahun-dari-galeri-indonesia-kaya-bergerakaktif-dengan-menaridirumahaja-dan-menikmati-sajian-kuliner-dari-kebun-ke-dapur [Accessed 11 Jun 2021] 
40 World Health Organisation. Smoke-Free movies: from evidence to action, 3rd edn, 2015. Available: https://apps.who.int/iris/rest/bitstreams/850394/retrieve [Accessed 1 Jun 2021].

41 Leonardi-Bee J, Nderi M, Britton J. Smoking in movies and smoking initiation in adolescents: systematic review and meta-analysis. Addiction 2016;111:1750-63.

42 Barnes B. There's No Smoking in Disney Films. What About When It Owns Fox? New York Times. Media, 2018. Available: https://www.nytimes.com/2018/04/25/business/ media/smoking-movies-disney-fox.html [Accessed 1 June 2021].

43 Romo V. Netflix promises to quit smoking on (most) original programming, 2019 Available: https://www.npr.org/2019/07/04/738719658/netflix-promises-to-quitsmoking-on-most-original-programming [Accessed 1 Jun 2021].

44 Initiative T. While you were streaming: smoking on demand, 2019. Available: https:// truthinitiative.org/sites/default/files/media/files/2019/07/WUWS-SOD-FINAL.pdf [Accessed 11 Jun 2021].

45 Media S. Onscreen tobacco database, 2021. Available: https://smokefreemedia.ucsf. edu/sfm-media [Accessed 1 Jun 2021].

46 WHO Framework Convention on Tobacco Control Secretariat. Article 13. Demand reduction measures. C2722 - Ban covering the domestic internet. Report Charts, 2020. Available: https://untobaccocontrol.org/impldb/indicator-report/?wpdtvar=3.2. 7.2.b [Accessed 1 Jun 2021].

47 Campaign for Tobacco-Free Kids. Where there's smoke. Available: https://www. takeapart.org/wheretheressmoke/ [Accessed 1 Jun 2021].

48 Klein EG, Czaplicki L, Berman M, et al. Visual Attention to the Use of \#ad versus \#sponsored on e-Cigarette Influencer Posts on Social Media: A Randomized Experiment. J Health Commun 2020:25:925-30.

49 Facebook. Advertising policies. Prohibited content, 2021. Available: https://www. facebook.com/policies/ads/\# [Accessed 1 Jun 2021].

50 Instagram. Ads on Instagram, 2021. Available: https://help.instagram.com/ 1415228085373580 [Accessed 31 Aug 2021].

51 Twitter. Twitter ads policies, 2021. Available: https://business.twitter.com/en/help/adspolicies.html [Accessed 31 Aug 2021].

52 O'Brien EK, Hoffman L, Navarro MA, et al. Social media use by leading US e-cigarette, cigarette, smokeless tobacco, cigar and hookah brands. Tob Control 2020;29:e87-97.

53 Freeman B, Hefler M, Hunt D. Philip Morris International's use of Facebook to undermine Australian tobacco control laws. Public Health Res Pract 2019:29:e2931924.

54 Google. Advertising policies help. List of AD policies: dangerous products or services, 2021. Available: https://support.google.com/adwordspolicy/answer/6014299?hl=en [Accessed 1 Jun 2021].

55 Gosh D. Are we entering a new era of social media regulation? Harvard business review, 2021. Available: https://hbr.org/2021/01/are-we-entering-a-new-era-of-socialmedia-regulation [Accessed 1 Jun 2021].

56 STOP. A global tobacco industry watchdog. About. It's time to shine the light on the tobacco industry, 2021. Available: https://exposetobacco.org/about/ [Accessed 31 Aug 2021].

57 WHO Framework Convention on Tobacco Control Secretariat. Expert group report on tobacco advertising, promotion and sponsorship: Depiction of tobacco in entertainment media, 2018. Available: https://www.who.int/fctc/cop/Document-TAPS 1.pdf [Accessed 1Jun 2021].
58 Greenland S, Lužar K, Low D. Tobacco Csr, sustainability reporting, and the marketing paradox. In: Crowther D, Seifi S, eds. The Palgrave Handbook of corporate social responsibility. Cham: Palgrave Macmillan, 2020: 1-27.

59 Legg T, Peeters S, Chamberlain P, et al. The Philip Morris-funded foundation for a smoke-free world: Tax return sheds light on funding activities. Lancet 2019;393:2487-8.

60 Meade A. Philip Morris-sponsored articles in the Australian could breach tobacco advertising laws. The Guardian, 2020. Available: https://www.theguardian.com/ media/2020/nov/19/philip-morris-sponsored-articles-in-the-australian-could-breachtobacco-advertising-laws [Accessed 11 Jun 2021].

61 Watts C, Hefler M, Freeman B. 'We have a rich heritage and, we believe, a bright future': how transnational tobacco companies are using Twitter to oppose policy and shape their public identity. Tob Control 2019;28:227-32.

62 Campaign for Tobacco-Free Kids. Tobacco cortrol laws. Policy Area: Advertising Promotion \& Sponsorship, forms: Vending machines laws status of: Banned, 2021. Available: https://www.tobaccocontrollaws.org/legislation/finder/\#_adban-tab [Accessed 11 Jun 2021]

63 Azzahro EA, Dewi DMSK, Puspikawati SI, et al. Two tobacco retailer programmes in Banyuwangi, Indonesia: a qualitative study. Tob Control 2021:30:e50-5.

64 Hefler M, Gartner CE. The tobacco industry in the time of COVID-19: time to shut it down? Tob Control 2020;29:245-6.

65 Kennedy RD, Grant A, Spires M, et al. Point-of-sale tobacco advertising and display bans: policy evaluation study in five Russian cities. JMIR Public Health Surveill 2017;3:e52.

66 Chido-Amajuoyi OG, Mantey DS, Clendennen SL, et al. Association of tobacco advertising, promotion and sponsorship (TAPS) exposure and cigarette use among Nigerian adolescents: implications for current practices, products and policies. BMJ Glob Health 2017;2:e000357.

67 Tan ASL, Hanby EP, Sanders-Jackson A, et al. Inequities in tobacco advertising exposure among young adult sexual, racial and ethnic minorities: examining intersectionality of sexual orientation with race and ethnicity. Tob Control 2021;30:84-93.

68 Kahnert S, Demjén T, Tountas Y, et al. Extent and correlates of self-reported exposure to tobacco advertising, promotion, and sponsorship in smokers: findings from the EUREST-PLUS ITC Europe surveys. Tob Induc Dis 2018;16.

69 Li L, Borland R, Yong H-H, et al. Impact of Point-of-Sale tobacco display bans in Thailand: findings from the International tobacco control (ITC) Southeast Asia survey. Int J Environ Res Public Health 2015;12:9508-22.

70 Nicksic NE, Bono RS, Rudy AK, et al. Smoking status and racial/ethnic disparities in youth exposure to tobacco advertising. J Ethn Subst Abuse 2020:1-16.

71 da Silva ALO, Grilo G, Branco PAC. Tobacco industry strategies to prevent a ban on the display of tobacco products and changes to health warning labels on the packaging in Brazil. Tob Prev Cessat 2020;6:66.

72 Astuti PAS, Assunta M, Freeman B. Raising generation 'A': a case study of millennial tobacco company marketing in Indonesia. Tob Control 2018;27:e41-9.

73 Smith EA, Malone RE. An argument for phasing out sales of cigarettes. Tob Control 2020;29:703-8. 